\title{
The Role of Gender Factor in the Effect of Personality Traits on Entrepreneurship Tendency
}

\author{
Nilüfer Yörük Karakılıç \\ Associate Professor Dr., Faculty of Economics and Administrative Science, Department of \\ Management and Organization, Afyon Kocatepe University, Afyonkarahisar, Türkiye
}

\begin{abstract}
Entrepreneurship is one of the important economic phenomena of today. The entrepreneurs who put the initiatives into operation, which constitute the most fundamental building block of the economy, keep the interest above all periods. It can be stated that, it is tried to be increased with the support and incentives of the state and also with grants especially today. Entrepreneurship is a key element of economic development, employment creation and increasing the level of welfare which countries emphasize strongly. Entrepreneurship is the process of carrying the opportunities offered by the environment into a business activity. There are many characteristics that entrepreneurs who can see these opportunities should have, and as one of them, the entrepreneurial tendencies of university students who are candidates to become entrepreneurs and the personality traits considered as one of the factors affecting this tendency have been tried to be determined by considering the gender factor. In the study, it was aimed to determine the role of gender factor in the effect of personality traits of university students on their tendency to be entrepreneurs. For this purpose, data from 300 university students were obtained from the online questionnaires sent to university students. Reliability analysis and descriptive statistics were made with SPSS 16 for these data. For the analysis of the hypotheses, the structural equation model was applied in AMOS 19 program. It was determined that extraversion and openness to development dimension of personality traits affected entrepreneurship tendency. Additionally, it was determined that age and gender among demographic factors also affected the relationship between personality traits and entrepreneurship tendency.
\end{abstract}

Keywords: Personality Traits, Entrepreneurial Traits, Entrepreneurial Tendency

DOI: $10.7176 / \mathrm{EJBM} / 13-6-17$

Publication date:March $31^{\text {st }} 2021$

\section{Introduction}

In the most common definition in the literature, an entrepreneur is the person who takes the risk and seeks to gain profit by bringing together the factors of production. Entrepreneurship is the most fundamental element of an efficient economy. The most important condition of a developed economy is to support enterprises and entrepreneurs. Although entrepreneurship has been studied in many aspects in the literature, one of the most emphasized issues is the characteristics of entrepreneurs.

Entrepreneurship is the major source of employment, economic growth, and technological progress (Leutner et al., 2014). In the field of business administration, enterprise is expressed as starting a business with a purpose such as gaining profit or creating a new business or activity. An entrepreneur, on the other hand, is defined as a person who makes an effort within the framework of the specified goals and takes risks for this. The level of development of a society is determined by the surplus of individuals who can capture opportunities by seeing the opportunities and threats in the market and take the risks by calculating the risks and bring together the factors of production such as labour, raw materials, technology and capital.

The personality traits of entrepreneurs are among the subjects that are widely researched. Studies conducted in this context have shown that; three theories are emphasized in determining the personality traits of entrepreneurs. The first of these is the approach of Schumpeter (1935) who defines entrepreneurship as innovation. Entrepreneurs acknowledge the positive and negative consequences of their choices and the risks they undertake. According to Schumpeter, the entrepreneur does not have to have a big idea; on the contrary, the entrepreneur solves the problems with a pragmatic perspective. The second theory is about interventional orientation. This approach is firm orientation, and defines the requirements that include the entrepreneurial business. With this approach, factors such as competitive aggressiveness, proactivity, risk taking, innovation and autonomy have been focused on and associated all these factors with the establishment of a new firm. The third theory is shaped within the framework of McClelland's theory of the need to succeed which defines entrepreneurship as the need for success and the need for power. In this context, entrepreneurship refers to a process that emerges as a result of people's need to gain power or a need to succeed (Çetin \& Varoğlu, 2009: 56).

In the study, it was aimed to determine the role of personality traits and gender in this process which are considered to be an important factor in determining entrepreneurship tendency. In the research, in order to determine the role of gender factor in the effect of personality traits on entrepreneurship tendency, a questionnaire including expressions aimed at determining demographic factors, dimensions of personality traits and entrepreneurial tendency was prepared. For the use of the questionnaire, the ethical approval report of Afyon 
Kocatepe University Social and Human Sciences Scientific Research and Publication Ethics Board decision number 2020/251 was received. After the ethical approval of the research, the questionnaire application process took place.

\section{Conceptual Framework}

In the conceptual framework of the research, personality traits and entrepreneurship concept were emphasized.

\subsection{Personality}

The concept of personality is derived from the word "persona" which is a Latin word meaning mask. What is meant by this concept is that it is a set of personal and continuous characteristics that separate people from each other (Ülker \& Akan, 2019:247).

Personality in its simplest form can be expressed as the lifestyle of the individual, just as culture shows the lifestyle of a society. However, goodness, evil, honesty, wrongness, ugliness, talent, beauty, intelligence, education, emotion, joy, grief, anger, belief, happiness, friendship, traditionalism, socialism, self-interest, height, eye colour, sincerity, It has many characteristics such as talkativeness, jealousy and irritability. In this sense, it is actually everything that concerns a person. Everyone has a personality that includes all these positive and negative characteristics and differentiates the person from other individuals (Eroğlu, 2011:207). Personality traits refer to a long-term, unique and fixed pattern shown in terms of thoughts, behaviour and emotions that affect an individual's attitude and behaviour towards all facts and events (Ding et al., 2020).

Five factor personality traits were used in the study. The work of researchers such as Allport \& Odbert (1936) and Thurstone (1934) were the first steps of the five factor personality model. It was determined by Costa \& McCrae (1985) that personality consists of five factors by measuring the behavioural variables called "factors." (Develioğlu \& Tekin, 2013). The five-factor personality model consists of sub-dimensions of extraversion, agreeableness, conscientiousness, neuroticism and openness to development (Hachana et al., 2018; Murugesan \& Jayavelu, 2017; Leutner et al., 2014).

\subsection{Entrepreneurship}

There seems to be a lack of consensus on the definition and meaning of the word "entrepreneurship". McClelland (1961), for example, defines this as a dynamic process created and managed by an individual who seeks to exploit economic innovation to create new value in the market to achieve a specific need (Adekiya \& Ibrahim, 2016). According to Gartner (1988), entrepreneurship is the creation of organizations. What distinguishes entrepreneurs from non-entrepreneurs is that entrepreneurs create organizations while non-entrepreneurs do not. In behavioural approaches to entrepreneurship study, an entrepreneur is seen as a series of activities involved in creating an organization, while an entrepreneur can be specified as a set of personality traits in trait approaches (Gartner, 1988). It can be defined as individuals who see an opportunity for goods and services that others cannot see and transform it into a business idea, take all the risks and organize production factors, follow technological developments and are open to innovations that may occur (Akkuş et al., 2019). It can be said that the concept of entrepreneurship has been among the attractive subjects that have been researched in the literature in many aspects since its use. Generally, they are economic activities created to produce goods or services for human needs by combining production factors in order to make a profit.

Table 1: Entrepreneur Definition

\begin{tabular}{l|l|l}
\hline Year & Author & Entrepreneur Definition \\
\hline 1725 & Richard Cantillon & Entrepreneurship is defined as creating capital while considering risks. \\
\hline 1797 & Beaudeau & Entrepreneurship is the fulfilment of the management function by undertaking the risks. \\
\hline 1803 & Jean Baptiste Say & $\begin{array}{l}\text { Entrepreneurship is the separation of the income obtained from the one obtained } \\
\text { by taking risks. }\end{array}$ \\
\hline 1876 & Francis Walker & $\begin{array}{l}\text { It is a comparison between the beneficiary of capital by taking interest and the } \\
\text { one who makes a profit by using entrepreneurial skills. }\end{array}$ \\
\hline $1934 /$ & $\begin{array}{l}\text { Joseph } \\
1950\end{array}$ Schumpeter & $\begin{array}{l}\text { Entrepreneurship is the process of innovation. The production of new products } \\
\text { and services is the process of using new technologies and ideas. }\end{array}$ \\
\hline 1961 & David McClelland & Entrepreneurship is investing in the market where you will take risks. \\
\hline 1964 & Peter Drucker & Entrepreneurship is an opportunity evaluation process. \\
\hline 1975 & Albert Shapero & Entrepreneurship is taking action despite the possibility of failure. \\
\hline 1980 & Karl Vesper & Entrepreneurship includes business people. \\
\hline 1983 & Gifford Pinchot & Entrepreneurship is starting a new business. \\
\hline 1985 & Robert Hisrich & Entrepreneurship is the process of producing goods and services for profit.
\end{tabular}

Source: Korkmaz, O. (2012), Üniversite öğrencilerinin girişimcilik eğilimlerini belirlemeye yönelik bir araştırma: Bülent Ecevit Üniversitesi örneği, Afyon Kocatepe Üniversitesi, İIBF Dergisi, 14(2). 
"The concept of entrepreneurship which is one of the indispensable elements of achieving basic economic goals, has been defined in different ways according to the field of science and classified according to various features. Defined by Cantillon in 1755 and then by Say in 1803 and currently accepted by Schumpeter (1911), entrepreneurship is defined as "doing business, undertaking, creating opportunities, meeting requests and needs through innovation and establishing a business" (İnce, 2018).

Entrepreneurship is defined as a process that is created to meet social needs, that is introduced by people who transform economic opportunities into investments or create economic opportunities, and that causes change in the economic system with the innovations it brings (İșcan \& Kaygın, 2011: 445). Within the framework of these definitions, it is a necessity for an entrepreneur to have certain characteristics. He is a responsible individual who can take risks, sees opportunities, has the necessary education and skills, attaches importance to innovative and creativity concepts.

\section{Literature Review}

Whether there is a relationship between personality traits and entrepreneurship is among the topics that are wondered in the literature.

Baron (1998) while examining the entrepreneurship characteristics in his study has sought an answer to the question of why some people can create opportunities for entrepreneurship while others cannot.

Çetin \& Varoğlu (2009) have evaluated whether personality traits are important for entrepreneurship. Doğaner \& Altunoğlu (2010) have examined the entrepreneurship tendencies of students of Business Administration Department in Nazilli. To this end, the data obtained from 229 students were evaluated. A significant relationship has been determined between entrepreneurial tendency and personality traits and the need to be creative and to succeed.

İşcan \& Kaygın (2011) have aimed to determine the entrepreneurship tendencies of university students in their study. For this purpose, Kafkas University and Kırıkkale University Faculty of Economics and Administrative Sciences applied a questionnaire to senior students and have tried to determine their entrepreneurship tendencies comparatively.

Leutner et al., (2014) have showed that the Big Five personality traits in their work reveal business intention, creation and success, but because narrow personality traits such as innovativeness also predict these results better than broad traits such as Conscientiousness and Extraversion. They have examined the relationship between outcomes.

Espiritu-Olmos \& Sastre- Castillo (2015) have compared business values and personality traits that affect entrepreneurial intention. They conducted analyses on 1210 students in their questionnaires and as a result, they have found that personality traits affect entrepreneurship tendency more.

Chan et al., (2015) have investigated the role of personality traits in the emergence of leadership and entrepreneurship. They have found that the five personality traits were associated with low risk aversion and proactive personality, entrepreneurship and leadership motivations, while high risk aversion was associated with a more professional-based, professional working motivation.

Walter \& Heinrichs (2015) have examined the relationship between individual variables and entrepreneurship tendency by examining the studies between in 1980-2009. They categorize repeatedly have analysed determinants into six perspectives (trait, cognitive, affective, intentions, learning, and economic), review empirical findings for each determinant and each perspective, investigate trends in the field, and propose avenues for future research.

Boz et al., (2016) have examined whether there is a relationship between personality traits and entrepreneurship tendency. In practice, they have conducted a field study with public-private sector employees in Çanakkale, and after face-to-face interviews with 461 people; they identified significant differences between entrepreneurs and salaried employees in the dimensions of personality's extraversion, compatibility, self-control, responsibility and openness to development.

Adekiya \& Ibrahim (2016) have tried to determine the entrepreneurship tendencies of students and the contribution of entrepreneurship education to this trend in their studies. For this, they conducted a survey on 357 students in Nigeria and as a result of the analysis; they found that entrepreneurship education was effective on the tendency to be entrepreneurs.

Uygun \& Güner (2016) have tried to identify entrepreneurship tendencies of young people who have received entrepreneurship training. In the analysis, significant relationships have determined between the entrepreneurship education received and the general entrepreneurship tendency and attitude towards entrepreneurship which constitute the sub-dimensions of the tendency, the social norm of the perception towards entrepreneurship, behavioural control and self-efficacy variables.

Sarıtaş \& Duran (2017) have aimed to identify the personal characteristics of students at Mehmet Akif Ersoy University and the factors that affect their entrepreneurial success. They tried to determine the relationship between personal characteristics and entrepreneurial success by analysing the questionnaires conducted on 487 students.

Murugesan \& Jayavelu (2017) have tried to investigate the effect of Big Five personality traits and self- 
efficacy on entrepreneurial intentions. It also has aimed to find out whether the impact of a set of personality traits and self-efficacy on entrepreneurial intention differs by gender. The results of the questionnaire, openness, neuroticism, conscientiousness and compatibility, and self-efficacy have found to be related to entrepreneurial intention.

İnce (2018) has tried to determine the entrepreneurial tendency of Generation $\mathrm{Z}$ in his study.

Ülker \& Akan (2019) analysed the questionnaires they conducted on 208 students studying at Tekirdağ Namık Kemal University in order to determine the effect of personality traits on career values, and as a result, they found a significant but weak relationship between humble-sincere personality traits and the entrepreneurial dimension of career value.

Sözcan \& Y1lmaz (2019) have analysed how the personality traits of Sakarya University students affect their entrepreneurial tendencies with SPSS. While a positive correlation was found between the extraverted, selfdisciplinary and openness to experience dimensions of personality and entrepreneurial tendency, a negative correlation was found between the emotional imbalance dimension and entrepreneurial tendency.

Zhao et al., (2010) have conducted a meta-analysis in order to determine the effects of personality on the entrepreneurship process. In their research, they determined that five major factors personality dimensions have related to four dimensions except the mildness one.

Yukongdi \& Lupo (2017) have examined the determinants of entrepreneurial intention in their studies. Specifically, the study has investigated the extent to which personality traits or situational factors influenced entrepreneurial intention and whether the relationship among the predictor variables and the intention to become entrepreneurs differed between men and women.

Sui et al., (2017) have aimed to determine the entrepreneurial self-efficacy, creative tendency, entrepreneurial motivation of university students after receiving entrepreneurship training. After the entrepreneurship training of the students, their entrepreneurial competition intentions decreased and their risk-taking rates have increased. They found that entrepreneurial education significantly have affected students' entrepreneurial self-efficacy, but not creative disposition and entrepreneurial motivation.

Holienka et al., (2018) have conducted a comparison with 130 sports and 124 pedagogy students in order to determine the importance of personality in entrepreneurial tendency.

Voni \& Rojuniah (2019) have tried to determine the effect of entrepreneurial characteristics (innovativeness, success, locus of control, risk taking, uncertainty, self-confidence and tolerance) on entrepreneurial tendency by demographic data based on age. To this aim, a survey was conducted on 120 students and as a result, it was seen that innovativeness, risk taking, locus of control, tolerance to uncertainty and self-confidence have increased entrepreneurship tendency, but tolerance to uncertainty with the mediation effect of the age factor have alleviated the increase in entrepreneurial tendency.

Badri \& Hachicha (2019) have examined the effect of entrepreneurship tendency on students' intention to start a business in their research on university students aged between 22, and 25 in Tunisia. As a result of their econometric analysis, they have tried to determine the effect of personal characteristics (age, gender and education) on entrepreneurship intention and have found that gender had no effect on this trend.

Zisser et al., (2019) have sought to examine the gender differences in personality traits of people with and without entrepreneurial intent to assess whether women who have intend to become entrepreneurs' exhibit certain tendencies that could be encouraged.

Murray \& Crammond (2020) have conducted a research on 75 students in a university in Scotland to determine the entrepreneurship tendencies of university students and have determined that the education received supports the entrepreneurial tendency.

Viinikainen et al., (2017) as part of human capital, personality characteristics affect individuals' productivity and therefore their entrepreneurial ability. Personality characteristics may further have affected individuals' entrepreneurial intentions and success through motivation. They have investigated the personality traits of the entrepreneur in their study.

\section{Research Design}

The application of the research was carried out on Afyon Kocatepe University students. The personality traits and entrepreneurship tendencies of the students were tried to be determined with the prepared questionnaires. 
Research Model and Hypotheses

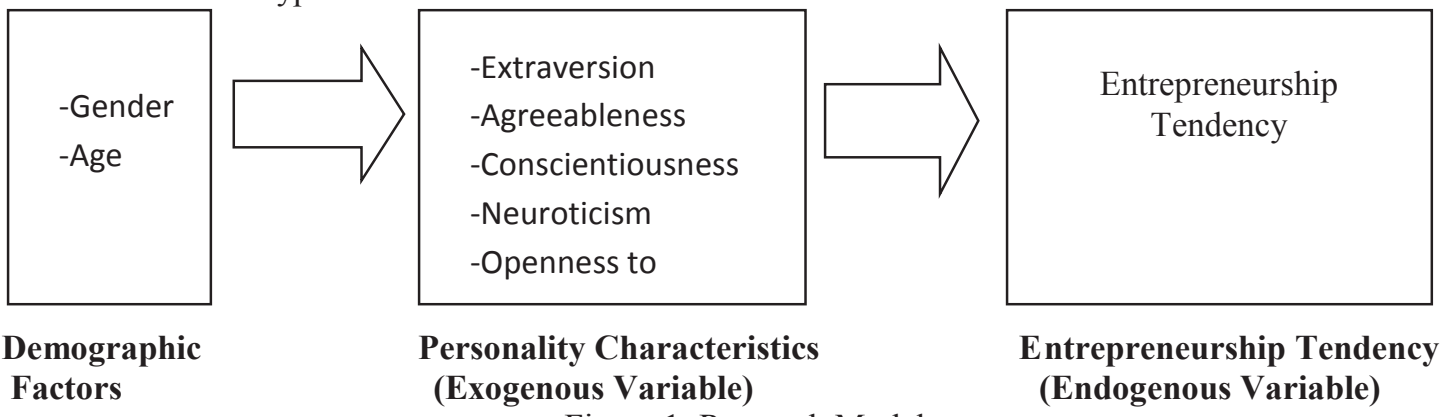

H1. Extraversion from personality traits affects entrepreneurial tendency.

$\mathrm{H} 2$. Among the personality traits, agreeableness affects the entrepreneurial tendency.

H3. Conscientiousness from personality traits affects entrepreneurial tendency.

H4. Neuroticism, one of the personality traits, affects the entrepreneurial tendency.

H5. Openness to development from personality traits affects entrepreneurial tendency.

H6. The effect of personality traits on entrepreneurial tendency differs according to the gender variable.

H7. The effect of personality traits on entrepreneurial tendency varies according to the age variable.

\subsection{Research Variables}

In the study, a questionnaire consisting of 44 statements have used to measure personality traits and a scale containing 17 statements for entrepreneurship tendency have used. The personality traits questionnaire has consisted of the dimensions of extraversion, mildness, self-control, neuroticism, and openness to development. Personality traits are exogenous variable, entrepreneurship tendency is endogenous variable in the study.

\subsection{Data Collection Method}

Personality traits scale was taken from the doctoral dissertation of Buluk (2020). Entrepreneurship tendency scale was obtained from the study of Uygun \& Güner (2016). The questionnaires of the study were conducted on the students studying at Afyon Kocatepe University. Through the online questionnaires sent to students, 300 usable data were reached.

\subsection{Data Valuation Method}

The research was carried out by sending online questionnaires to students studying at Afyon Kocatepe University. The surveys of the research have included two scales and demographic dimensions.

The first part has included questions for demographic characteristics (age, gender, and faculty). In the second part, in order to determine personality traits, the Personality trait scale using 5-point Likert type questions from (1) strongly agree to a (5) was used. In the third part, the scale of entrepreneurship tendency was used.

Validity and reliability analysis was performed to ensure the construct validity of the scales. After the data were entered into the SPSS 16.0 package program, confidence analysis and exploratory factor analysis were performed in SPSS and structural equation modelling was performed in AMOS 19 program to determine the effects of the data on each other.

\subsection{Validity test of the Scales Used in the Research}

With the AMOS 19 program to test the validity of the scales used; One-factor confirmatory factor analysis was performed for personality traits scale first level multi-factor model and entrepreneurial tendency scale. Since the fit values produced by the measurement models created to test the validity of the scales were not within acceptable limits, the modifications suggested by the AMOS program were made. The changes made in the scale as a result of the modifications are shown in Table 2, and the fit values produced by the measurement models are shown in Table3.

Table 2: Changes in Scale

\begin{tabular}{l|l|l|l}
\hline \multicolumn{2}{|c|}{ Scales } & Number of Statements & Number of Statements Issued \\
\hline \multirow{4}{*}{ Personality Traits Scale } & Agtraversion & 8 & 2 \\
\cline { 2 - 4 } & Conseableness & 9 & 1 \\
\cline { 2 - 4 } & Neuroticism & 9 & 3 \\
\cline { 2 - 4 } & Openness to development & 8 & 3 \\
\hline \multicolumn{2}{l}{ Entrepreneurship Tendency } & 10 & 4 \\
\hline
\end{tabular}

As seen in Table 2, 2 from the extraversion dimension of the personality traits scale, 1 from the agreeableness 
dimension, 3 from the conscientiousness dimension, 3 from the neuroticism dimension, and 4 from the openness to development dimension, and 2 from the entrepreneurial disposition dimension were removed.

Table 3: Fit Values of the Scales

\begin{tabular}{|c|c|c|c|c|c|c|c|}
\hline \multirow{6}{*}{$\begin{array}{l}\text { Personality } \\
\text { Traits Scale }\end{array}$} & & $x 2$ & Df & $x 2 / d f$ & GFI & CFI & RMSEA \\
\hline & Extraversion & 10,35 & 8 & 1,29 & 0,98 & 0,99 & 0,03 \\
\hline & Agreeableness & 26,93 & 19 & 1,41 & 0,98 & 0,98 & 0,03 \\
\hline & Conscientiousness & 18,51 & 7 & 2,64 & 0,98 & 0,98 & 0,07 \\
\hline & Neuroticism & 13,36 & 5 & 2,67 & 0,98 & 0,96 & 0,07 \\
\hline & Openness to development & 12,98 & 9 & 1,44 & 0,99 & 0,99 & 0,03 \\
\hline \multicolumn{2}{|c|}{ Entrepreneurship Tendency Scale } & 248,76 & 88 & 2,82 & 0,90 & 0,93 & 0,07 \\
\hline \multicolumn{2}{|c|}{ Good Fit Values } & & & $\leq 3$ & $\geq 90$ & $\geq 0,97$ & $\leq 0,05$ \\
\hline \multicolumn{2}{|c|}{ Acceptable Fit Values } & & & $\leq 5$ & $\begin{array}{l}0,89- \\
0,85\end{array}$ & $\geq 95$ & $\begin{array}{l}0,06- \\
0,08\end{array}$ \\
\hline
\end{tabular}

$\mathrm{p}>.05, \mathrm{x} 2=$ Chi- Square (Ki-kare); df= Degree of Freedom GFI= Goodness of Fit Index; CFI= Comparative Fit Index; RMSEA= Root Mean Square Error of Approximation. (Source: Meydan \& Şeşen, 2015: 37).

Considering the fit values of the scales, both scales provide the equation $\mathrm{X} 2 / \mathrm{df} \leq 3$ with their dimensions. It was determined that both scales fulfil the GFI value $\geq 85-89$, CFI value $\geq 95$, and RMSEA $\leq 0.06-0.08$.

\section{Findings}

The Cronbach Alpha coefficient and KMO value of the scales are indicated in the tables.

Table 4: Cronbach Alpha Coefficient of the Scales

\begin{tabular}{l|l}
\hline & Cronbach Alfa \\
\hline Personality Traits Scale &, 703 \\
\hline Entrepreneurship Tendency Scale &, 917 \\
\hline
\end{tabular}

It is seen in Table 4 that; personality traits scale is quite reliable, and entrepreneurial tendency scale is highly reliable.

- If $0.00 \leq \alpha<0.40$, the scale is not reliable,

- If $0.40 \leq \alpha<0.60$, the scale is at low reliability,

- If $0.60 \leq \alpha<0.80$, the scale is quite reliable,

- If $0.80 \leq \alpha<1.0$, the scale is a scale with high reliability.

Table 5: KMO Value of the Scales

\begin{tabular}{l|l|l}
\hline \multicolumn{2}{l}{ KMO and Bartlett's Test } & \\
\hline Kaiser-Meyer-Olkin Measure of Sampling Adequacy. &, 825 \\
\hline \multirow{2}{*}{$\begin{array}{l}\text { Bartlett's Test of } \\
\text { Sphericity }\end{array}$} & Approx. Chi-Square & $8,914 \mathrm{E} 3$ \\
\cline { 2 - 3 } & Df & 1830 \\
\cline { 2 - 3 } & Sig. &, 000 \\
\hline
\end{tabular}

- KMO: 1,00 KMO0,90 = Perfect level

- KMO: 0,90 KMO 0,80= Good level

- $\quad \mathrm{KMO}: 0,80 \mathrm{KMO} 0,70=$ Moderate

- KMO: 0,70 KMO0,60 = Weak level

- $\mathrm{KMO}: 0,60 \mathrm{KMO}=$ Bad level

Looking at the standard criteria, the KMO value of the research is well worth it. 
Table 6: Correlation Female and Male

\begin{tabular}{|c|c|c|c|c|}
\hline & & & Mean Personality & Mean Entrepreneurship \\
\hline \multirow{6}{*}{ Correlation Female } & \multirow[t]{3}{*}{ Mean Personality } & Correlation Coefficient & 1,000 & $296^{* *}$ \\
\hline & & Sig. (1-tailed) & . &, 000 \\
\hline & & $\mathrm{N}$ & 137 & 137 \\
\hline & \multirow{3}{*}{$\begin{array}{l}\text { Mean } \\
\text { Entrepreneurship }\end{array}$} & Correlation Coefficient &, $296^{* *}$ & 1,000 \\
\hline & & Sig. (1-tailed) &, 000 & . \\
\hline & & $\mathrm{N}$ & 137 & 137 \\
\hline \multirow{6}{*}{ Correlation Male } & \multirow[t]{3}{*}{ Mean Personality } & Correlation Coefficient & 1,000 & $215^{* *}$ \\
\hline & & Sig. (1-tailed) & . &, 003 \\
\hline & & $\mathrm{N}$ & 163 & 163 \\
\hline & \multirow{3}{*}{$\begin{array}{l}\text { Mean } \\
\text { Entrepreneurship }\end{array}$} & Correlation Coefficient &, $215^{* *}$ & 1,000 \\
\hline & & Sig. (1-tailed) &, 003 & . \\
\hline & & $\mathrm{N}$ & 163 & 163 \\
\hline
\end{tabular}

Considering the relationship between the variables, if gender is female between personality traits and entrepreneurship tendency; $\mathrm{p}$ : $0.00 \mathrm{p}<0.01$ in the correlation analysis test performed for the male participants, as it provided p: $0.003 \mathrm{p}<0.01$, a positive significant relationship was found.

\subsection{Demographic Characteristics of the Participants}

In the research, demographic characteristics of the students were examined from three different perspectives: gender, age, and the faculty of education. General information about the characteristics of the students participating in the study was obtained by examining the frequency and percentage tables of the students regarding demographic variables. The total number of participants participating in the survey has been 300 . Table 7 gives the frequency and percentage values of the demographic characteristics of the participants.

Table 7: Demographic Characteristics of the Participants

\begin{tabular}{l|l|l|l|l}
\hline & & Number & $\%$ & Sum \% \\
\hline \multirow{2}{*}{ Gender } & Female & 137 & 45.7 & 45.7 \\
\cline { 2 - 6 } & Male & 163 & 54.3 & 100.0 \\
\hline \multirow{2}{*}{ Age } & $17-20$ & 47 & 15.7 & 15.7 \\
\cline { 2 - 6 } & $21-24$ & 217 & 72.3 & 72.3 \\
& $25-28$ & 36 & 12.0 & 12.0 \\
\hline \multirow{2}{*}{ Faculties } & Faculty of Economics and Administrative Sciences, Tourism, Islamic Studies,, & 222 & 74,0 & 74,0 \\
& Law & 38 & 12,7 & 86,7 \\
\cline { 2 - 6 } & Engineering, Architecture, Vocational School, Health Sciences & 40 & 13,3 & 100,0 \\
\cline { 2 - 6 } & Education, Technology, Faculty of Arts and Sciences & 300 & 100.0 & \\
\hline
\end{tabular}

137 (45.7\%) of those answering these 300 questionnaires are women and 163 (54.3\%) are men. 47 (15.7\%) of the students in the sample are 17-20 years old, $217(72.3 \%)$ are $21-24$ years old, and 36 (12\%) are in the 25-28 age group. Of the sample, $222(74.0 \%)$ are students studying at Faculty of Economics and Administrative Sciences, Tourism, Islamic Sciences, Law Faculty, 38 (12.7\%) Engineering, Architecture, Vocational School, Health Sciences Faculty and 40 (13.3\%) Education, Technology, Arts and Sciences. 


\subsection{Structural Equation Model}

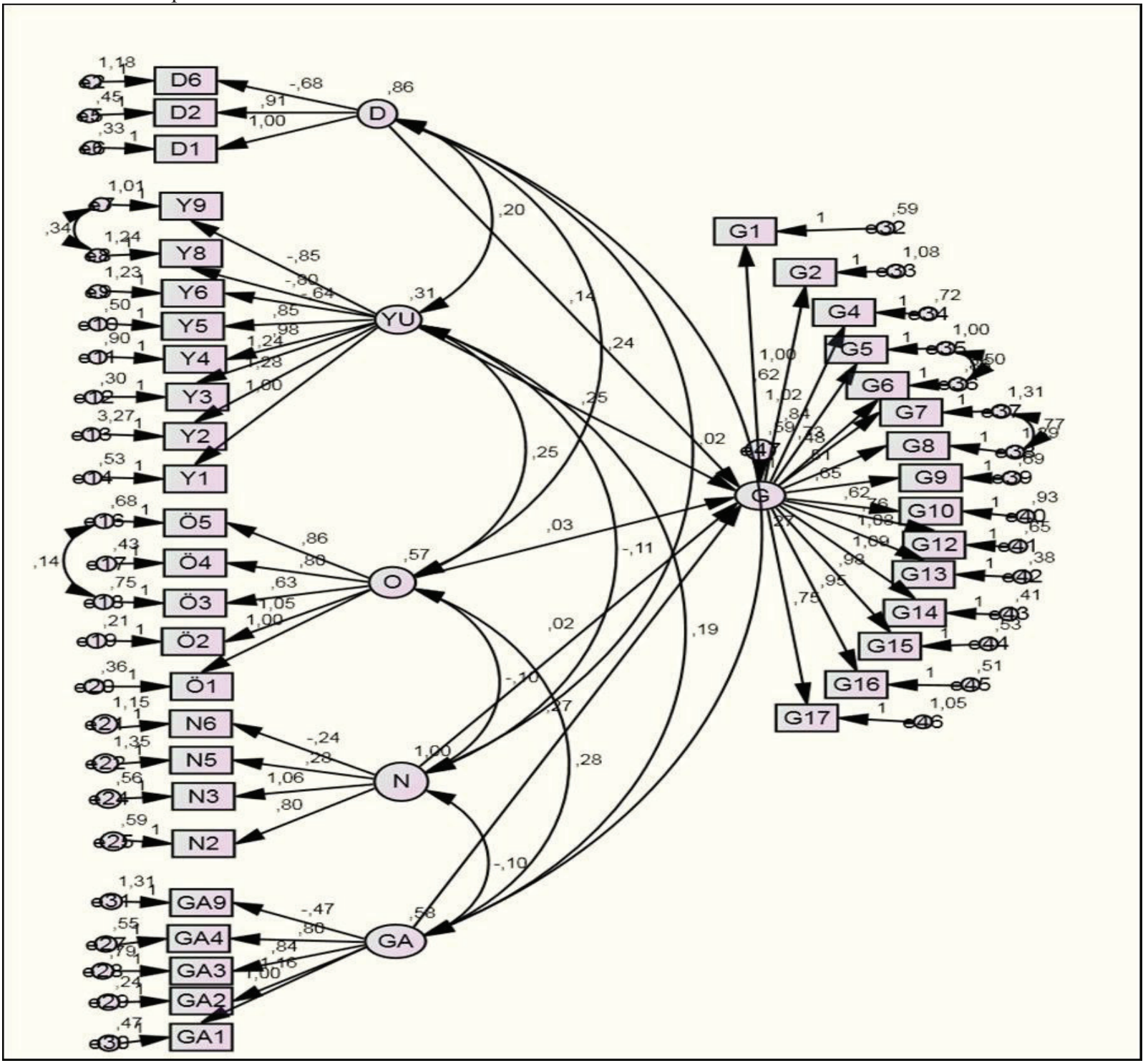

Figure 2: Structural Equation Model

Since the fit values of the model shown in Figure 2 are not within acceptable limits, 2 expressions were removed from the personality traits scale. As a result of the modification, it was determined that the fit values of the model were within the limits of good fit values and it was observed that sufficient evidence was provided that the model was structurally suitable. Model fit values are shown in Table 8.

Table 8: Structural Equation Model Fit Values

\begin{tabular}{l|l|l|c|l|l|l}
\hline & $\mathrm{x}^{2}$ & $\mathrm{Df}$ & $\mathrm{x}^{2} / \mathrm{df}$ & GFI & CFI & RMSEA \\
\hline Before the phrases come out & 1572,311 & 800 & 1,96 & 0,81 & 0,85 & 0,05 \\
\hline After the phrases come out & 1381,536 & 721 & 1,91 & 0,82 & 0,87 & 0,05 \\
\hline Good Fit Values & & & $\leq 3$ & $\geq 90$ & $\geq 0,97$ & $\leq 0,05$ \\
\hline Acceptable Fit Values & & & $\leq 5$ & $\begin{array}{l}0,89- \\
0,85\end{array}$ & $\geq 95$ & $0,06-0,08$ \\
\hline
\end{tabular}

Coefficients, standard error, $\mathrm{p}$ and $\mathrm{x}^{2}$ values among variables according to the created model are shown in Table 9. 
Table 9: coefficients, standard error and $\mathrm{p}$ values between variables

\begin{tabular}{|c|c|c|c|c|c|c|c|}
\hline Variables & & & $a$ & $\sqrt[1]{2}$ & a & 约 & 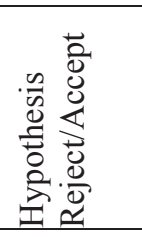 \\
\hline $\begin{array}{l}\text { H1.Exversionism among } \\
\text { personality traits affects } \\
\text { entrepreneurship tendency. }\end{array}$ & & & 0,15 & 0,06 & 0,03 & 2,075 & ACCEPT \\
\hline $\begin{array}{l}\text { H2. Among the personality } \\
\text { traits, agreeableness affects } \\
\text { the entrepreneurial tendency. }\end{array}$ & & & 0,16 & 0,25 & 0,07 & 1,788 & REJECT \\
\hline $\begin{array}{l}\text { H3. Conscientiousness from } \\
\text { personality traits affects } \\
\text { entrepreneurial tendency. }\end{array}$ & & & 0,03 & 0,09 & 0,73 & 0,345 & REJECT \\
\hline $\begin{array}{l}\text { H4. Neuroticism, one of the } \\
\text { personality traits, affects the } \\
\text { entrepreneurial tendency. }\end{array}$ & & & 0,02 & 0,05 & 0,75 & 0,313 & REJECT \\
\hline $\begin{array}{l}\text { H5. Openness to development } \\
\text { from personality traits affects } \\
\text { entrepreneurial tendency. }\end{array}$ & & & 0,23 & 0,08 & 0,02 & 3,034 & ACCEPT \\
\hline \multirow{10}{*}{$\begin{array}{l}\text { H6.The effect of personality } \\
\text { traits on entrepreneurial } \\
\text { tendency differs according to } \\
\text { gender variable }\end{array}$} & \multirow{5}{*}{ 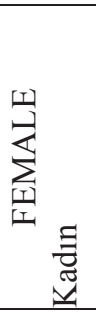 } & Extraversion & 0,05 & 0,09 & 0,53 & 0,61 & \multirow{10}{*}{ ACCEPT } \\
\hline & & Agreeableness & 0,09 & 0,19 & 0,47 & 0,71 & \\
\hline & & Conscientiousness & 0,00 & 0,13 & 0,95 & 0,05 & \\
\hline & & Neuroticism & 0,07 & 0,08 & 0,44 & 0,77 & \\
\hline & & $\begin{array}{l}\text { Openness } \\
\text { development }\end{array}$ & 0,40 & 0,15 & $* * *$ & 3,55 & \\
\hline & \multirow{5}{*}{ 告 } & Extraversion & 0,22 & 0,09 & 0,03 & 2,06 & \\
\hline & & Agreeableness & 0,31 & 0,22 & 0,02 & 2,28 & \\
\hline & & Conscientiousness & 0,06 & 0,14 & 0,57 & 0,55 & \\
\hline & & Neuroticism & $-0,08$ & 0,07 & 0,33 & $-0,96$ & \\
\hline & & $\begin{array}{l}\text { Openness } \\
\text { development }\end{array}$ & $-0,03$ & 0,11 & 0,76 & $-0,29$ & \\
\hline \multirow{15}{*}{$\begin{array}{l}\text { H7. The effect of personality } \\
\text { traits on entrepreneurial } \\
\text { tendency differs according to } \\
\text { the age variable. }\end{array}$} & \multirow{5}{*}{ 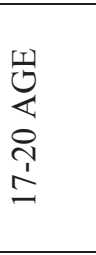 } & Extraversion & $-0,18$ & 0,16 & 0,35 & $-0,92$ & \multirow{15}{*}{ ACCEPT } \\
\hline & & Agreeableness & 0,21 & 0,18 & 0,31 & 1,00 & \\
\hline & & Conscientiousness & $-0,02$ & 0,13 & 0,89 & $-0,13$ & \\
\hline & & Neuroticism & $-0,05$ & 0,10 & 0,74 & $-0,33$ & \\
\hline & & $\begin{array}{l}\text { Openness } \\
\text { development }\end{array}$ & 0,27 & 0,16 & 0,20 & 1,27 & \\
\hline & \multirow{5}{*}{ 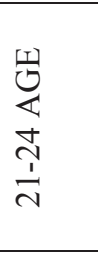 } & Extraversion & 0,20 & 0,08 & 0,01 & 2,44 & \\
\hline & & Agreeableness & 0,14 & 0,22 & 0,17 & 1,35 & \\
\hline & & Conscientiousness & $-0,04$ & 0,12 & 0,66 & $-0,42$ & \\
\hline & & Neuroticism & 0,07 & 0,07 & 0,33 & 0,96 & \\
\hline & & $\begin{array}{l}\text { Openness } \\
\text { development }\end{array}$ & 0,27 & 0,12 & 0,00 & 2,81 & \\
\hline & \multirow{5}{*}{ 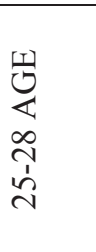 } & Extraversion & 0,01 & 0,18 & 0,96 & 0,04 & \\
\hline & & Agreeableness & 0,39 & 0,20 & 0,20 & 1,26 & \\
\hline & & Conscientiousness & 0,06 & 0,21 & 0,78 & 0,27 & \\
\hline & & Neuroticism & $-0,09$ & 0,11 & 0,67 & $-0,42$ & \\
\hline & & $\begin{array}{l}\text { Openness } \\
\text { development }\end{array}$ & 0,28 & 0,13 & 0,13 & 1,50 & \\
\hline
\end{tabular}

When the results of the analysis are examined;

H1. Extraversion from personality traits affects entrepreneurial tendency. Since $p=0.03 p<0.05$, there is a significant difference and the H1 hypothesis is accepted. 
H2. Among the personality traits, agreeableness affects the entrepreneurial tendency. Since $p=0.07 p>0.05$, there is no significant difference and the $\mathrm{H} 2$ hypothesis is rejected.

H3. Conscientiousness from personality traits affects entrepreneurial tendency. Since $p=0.73 p>0.05$, there is no significant difference and the $\mathrm{H} 3$ hypothesis is rejected.

H4. Neuroticism, one of the personality traits, affects the entrepreneurial tendency. Since $p=0.75 p>0.05$, there is no significant difference and the $\mathrm{H} 4$ hypothesis is rejected.

H5. Openness to development from personality traits affects entrepreneurial tendency. Since $p=0.02 p<0.05$, there is a significant difference and the H5 hypothesis is accepted.

H6. The effect of personality traits on entrepreneurial tendency differs according to the gender variable. Since the dimension of openness to development in the effect of personality traits of female gender on entrepreneurship tendency is $\mathrm{p}$ value: $* * *, \mathrm{p}<0.00$ and the effect of personality traits of male gender on entrepreneurial tendency, extroversion p value: 0.03 , amenability p value: 0 , since $02 p<0.05$, there is a significant difference and the H6 hypothesis is accepted.

H7. The effect of personality traits on entrepreneurial tendency varies according to the age variable. There is a significant difference in the effect of personality traits on entrepreneurial tendencies of participants aged 21-24, as extraversion $p$ value is 0.01 and openness $p$ value is $0.00 p<0.05$, and the $H 7$ hypothesis is accepted.

\section{Conclusion, Discussion and Suggestions}

The most basic building blocks of the economy namely the organizations we define as enterprises, are the most important indicators of the development level of a country. The more production can be achieved in a country, the more value added value and economic benefit, as well as employment creation will be achieved. For this reason, states, governments, chambers of commerce, educational institutions, communal and social institutions and organizations, as well as associations and foundations established for this purpose, are making efforts to increase the number of entrepreneurs. In order to increase the number of entrepreneurs who play an important role in increasing the economic level and the welfare level of the country, all segments of the society have a duty and universities support the process with the trainings they provide in this direction and they should. In line with the results of the research conducted in this direction, organizing the content of the education and courses and organizing entrepreneur training programs will be appropriate efforts. When the analysis of the research on this subject is examined, it is found that the entrepreneurship tendencies of university students are in line with other studies in the literature (İnce, 2018; Sarıtaş \& Duran, 2017; Göktaş \& Kazaferoğlu, 2018; İşcan \& Kaygın, 2018; Korkmaz, 2012; Zhao et al., 2010; Voni \& Rojuniah, 2019).

The analysis made in this research has showed that personality traits are effective on entrepreneurial intention. At the same time, according to the five-factor personality test used in the study, it has been determined that extraversion and openness to development have an effect on entrepreneurial tendency since personality traits have provided the equation $\mathrm{p}<0.05$. In other words, it is determined that students who are extraverted and open to development and innovation have a high tendency to be entrepreneurs and to create an enterprise. In this study, the role of gender factor in the effect of personality traits on entrepreneurial tendency is also evaluated and the entrepreneurial tendency of the students who are female participants with the personality trait of openness to development provided the equality of $\mathrm{p}<0.05$, the extraversion of the male participants, providing effect has been determined. In this sense, the hypothesis that gender factor personality traits have an effect on entrepreneurial tendency is accepted. In addition, considering the age factor, there is a significant difference in the effect of personality traits of the participants between the ages of 21-24 on entrepreneurial tendency since the extraversion $\mathrm{p}$ value is 0.01 and the openness to development $\mathrm{p}$ value is $0.00 \mathrm{p}<0.05$ and the hypothesis is accepted.

The research is carried out by applying a questionnaire to Afyon Kocatepe University students. Considering the gender dimension, it is determined that the personality traits dimensions and the entrepreneurial tendency are effective. In this state, the constraints of the research although considered to be an important contribution to the literature only create Afyon Kocatepe more reliable results with that in the not with students at the university participants across Turkey studying other university students make comparisons to the inclusion in the deals are thought that might be the case.

\section{References}

Adekiya, A.A. \& Ibrahim, F. (2016). Entrepreneurship intention among students the antecedent role of culture and entrepreneurship training and development, The International Journal Of Management Education 14, 116132.

Akkuş, Y., Akdoğan, Ç. \& Akyol, A. (2019). Girişimcilik niyetini etkileyen temel kişilik özellikleri ve girişimci kişilik boyutları: Trakya Örneği, (Effects of main personality traits and entrepreneur personality aspects on entrepreneurship intention: a sample of thrace ), Kırklareli Üniversitesi Sosyal Bilimler Dergisi, 3(1), 1-13.

Antoncic, B., Bratkovic K., Tina, S.,G. \& DeNoble, A.F. (Jul2015). The big five personality-entrepreneurship relationship: evidence from Slovenia, Journal of Small Business Management. 53 (3), 819-841. 23p. 7 Charts, 
5 Graphs. DOI: 10.1111/jsbm.12089.

Baron, R.A. (1998). Cognitive mechanisms in entrepreneurship: why and when enterpreneurs think differently than other people, .Journal of Business Venturing 13, 275-294.

Boz, M., Buluk, B., Aydınkaya, G.. \& Arslantaş, Y. (2016). Kişilik özellikleri ile girişimcilik eğilimi arasındaki ilişki: Çanakkale örneği. (The relationship between personality traits and entrepreneurial propensity: Canakkale case) Manas Sosyal Araştırmalar Dergisi, 5(5), 1-10.

Buluk, B. (2020). Statü temelli turizm tüketimi davranışında materyalizm, kültürel değerler ve kişilik özelliklerinin rolü, (The role of materialism, cultural values and personality traits in status-based tourism consumption behavior), Çanakkale Onsekiz Mart Üniversitesi Doktora Tezi.

Çetin, F. \& Varoğlu, A. K. (2009). Özellikler bağlamında girişimcinin beş faktör kişilik örüntüsü. (The entrepreneur's five-factor personality pattern in terms of traits), Savunma Bilimleri Dergisi, 8(2), 51-66.

Chan, K., Uy, M.A., Chernyshenko, O.S., Ringo Ho, M. \& Sam, Y.(2015). Personality and entrepreneurial, professional and leadership motivations, Personality and Individual Differences 77, 161-166

Develioğlu, K. \& Tekin, Ö. A. (2013). Beş faktör kişilik özellikleri ve yabancılaşma arasındaki ilişki: beş yıldızlı otel çalş̧anları üzerine bir uygulama. (The relationship between five-factor personality traits and alienation: an application on five-star hotel employees). Süleyman Demirel Üniversitesi İktisadi Ve İdari Bilimler Fakültesi Dergisi, 18(2), 15-30.

Ding, Y., Zheng, Y., Huang, J. \& Zheng, T. (2020). An online personality trait mining approach based on cluster analysis. International Symposium on Educational Technology (ISET) ISET Educational Technology (ISET), 258-262, Aug, 2020; IEEE Language: English, Veritabanı: IEEE Xplore Digital Library.

Doğaner, M. \& Altunoğlu, A. E. (2010). Adnan Menderes Üniversitesi Nazilli İktisadi Ve İdari Bilimler Fakültesi İşletme bölümü öğrencilerinin girişimcilik eğilimleri. (Entrepreneurship tendencies of Adnan Menderes University Nazilli Faculty of Economics and Administrative Sciences Department of Business Administration Students), Organizasyon ve Yönetim Bilimleri Dergisi, 2(2), 103-110.

Er Ülker, F. \& Balkan Akan, B. (2019). Bireylerin bazı kişilik özelliklerinin girișimci kariyer değerine olan etkisi: önlisans öğrencilerinin girişimcilik eğilimleri üzerine bir araştırma. (The effect of some personality traits of individuals on entrepreneurial career value: a study on the entrepreneurial tendencies of associate degree students), Academic Review of Economics \& Administrative Sciences, 12(2).

Eroğlu, F. (2011). Davranış Bilimleri, (Behavioral sciences), 11. Baskı, Beta Basım, İstanbul.

Espíritu-Olmos, R. \& Sastre-Castillo, M. A.(2015) Personality traits versus work values: comparing psychological theories on entrepreneurial intention, Journal of Business Research , 68, 1595-1598.

Gartner, Q.B. (1988). "Who is an entrepreneur?" Is the wrong question, American Journal of Small Business, 12 (4), 11-32. 22p. DOI: $10.1177 / 104225878801200401$.

Gencay, E. \& Döven, M.S. (2019). Girişimci kişilik özelliklerinin girişimcilik niyetine etkisi: mersin üniversitesi'nde bir araştırma, (The effect of entrepreneurial personality traits on entrepreneurial intention: a research at mersin university), Stratejik Yönetim Araștırmaları Dergisi, 2 (1), 89-123.

Göktaş, P. \& Kazaferoğlu, E. (2018). Kişilik özellikleri ile girişimcilik eğilimi arasındaki ilişki: Süleyman Demirel Üniversitesi Öğrencileri Üzerine Bir Araştırma. (The relationship between personality traits and entrepreneurship tendency: a study on Süleyman Demirel University students), Mehmet Akif Ersoy Üniversitesi İktisadi Ve İdari Bilimler Fakültesi Dergisi, 5(1), 39-63.

Hachana, R., Berraies, S. \& Ftiti, Z. (2018). Identifying personality traits associated with entrepreneurial success: does gender matter?, Journal of Innovation Economics \& Management 2018/3 (27) , p. 169-193.

Holienka, M., Holienková, J. \& Holienka, M. (2018). Sports as a stepping-stone for entrepreneurship: examining sports university students. Acta Universitatis Agriculturae Et Silviculturae Mendelianae Brunensis, 66(6), $1485-1496$

İnce, F. (2018). Z Kuşağının girişimcilik eğilimi: üniversite öğrencileri üzerinde bir araştırma, (Entrepreneurship tendency of generation z: a study on university students), Pamukkale Üniversitesi Sosyal Bilimler Enstitüsü Dergisi, 32, 105-113.

İşcan, Ö. F. \& Kaygın, E. (2011). Potansiyel girişimciler olarak üniversite öğrencilerinin girişimcilik eğilimlerini belirlemeye yönelik bir araştırma. (A research to determine entrepreneurship tendencies of university students as potential entrepreneurs), Organizasyon Ve Yönetim Bilimleri Dergisi, 3(2), 275-286.

Korkmaz, O. (2012). Üniversite öğrencilerinin girişimcilik eğilimlerini belirlemeye yönelik bir araştırma: Bülent Ecevit Üniversitesi Örneği, (A research to determine the entrepreneurship tendencies of university students: The case of Bülent Ecevit University), Afyon Kocatepe Üniversitesi İIBF Dergisi, 14 (2).

Leutner, F., Ahmetoglu, G., Akthar, R. \& Chamorro-Premuzic, T. (2014). The relationship between the entrepreneurial personality and the big five personality traits, Personality and Individual Differences , 63, $58-63$

Meydan, C. \& Şeşen, H. (2015). Yapısal eşitlik modeli AMOS Uygulamaları, (Structural equation model AMOS applications), Detay Yayıncılık: Ankara. 
Murray, A. \& Crammond, R.J. (2020). Witnessing entrepreneurial perceptions and proclivity in university students developing a process model, Education and Training, 62 (4), 459-481. DOI 10.1108/ET-03-2019-0052.

Murugesan, R. \& Jayavelu, R. (2017). The influence of big five personality traits and self-efficacy on entrepreneurial intention:the role of gender, Journal of Entrepreneurship and Innovation in Emerging Economies 3(1) 41-61.

Sarıtaş, A. \& Duran, G. (2017). Üniversite öğrencilerinin girişimcilik eğilimlerinin tespitine ilişkin bir araştırma. (A study on the determination of university students' entrepreneurship tendencies), Anemon Muş Alparslan Üniversitesi Sosyal Bilimler Dergisi, 5(1), 147-165.

Sözcan, Z. \& Yılmaz, T. (2019). Kişilik özelliklerinin girişimcilik eğilimi üzerine etkisi: Sakarya Üniversitesi örneği, (The effect of personality traits on entrepreneurship tendency: the case of Sakarya University), Bilgi Sosyal Bilimler Dergisi, 21(1).

Sui, F. M., Chang, J. C., Hsiao, H. C. \& Su, S. C. (December 2017). A study on entrepreneurial education regarding college students' creative tendency, entrepreneurship self-efficacy and entrepreneurial motivation. International Conference On Industrial Engineering And Engineering Management (Ieem), 850-854.

Ülker, F. E. \& Akan, B. B. (2019). Bireylerin bazı kişilik özelliklerinin girişimci kariyer değerine olan etkisi: önlisans öğrencilerinin girişimcilik eğilimleri üzerine bir araştırma. (The effect of some personality traits of individuals on entrepreneurial career value: a study on the entrepreneurial tendencies of associate degree students), Ömer Halisdemir Üniversitesi İktisadi Ve İdari Bilimler Fakültesi Dergisi, 12(2), 146-159.

Uygun, M. \& Güner, E. (2016). Girişimcilik eğiliminin gelişiminde girişimcilik eğitiminin rolü, (The role of entrepreneurship education in the development of entrepreneurship tendency), Manas Sosyal Araştırmalar Dergisi, 5(5), 37-57.

Viinikainen, J., Heineck, G., Böckerman, P. , Hintsanend, M., Raitakarie, O. \& Pehkonena, J. (2017). Born entrepreneurs? adolescents' personality characteristics and entrepreneurship in adulthood, Journal of Business Venturing Insights 8 (2017) 9-12.

Voni, A. \& Rahmat, S. T. Y. (2019). Entrepreneurial characteristics on entrepreneurial tendencies as age moderated: a study on university Indonesia. Russian Journal of Agricultural and Socio-Economic Sciences, 89(5).

Walter, S. G. \& Heinrichs, S. (2015). Who becomes an entrepreneur? A 30-years-review of individual-level research, Journal of Small Business and Enterprise Development, 22 (2), 225-248.

Yukongdi, V. \& Lopa N. Z. (2017). Entrepreneurial intention: a study of individual, situational and gender differences, Journal of Small Business and Enterprise Development, 24( 2), 333-352.

Zhao, H., Seibert, S. E. \& Lumpkin, G. T. (2010). The relationship of personality to entrepreneurial intentions and performance: a meta-analytic review. Journal of Management, 36(2), 381-404.

Zisser, M. R., Johnson, S. L., Freeman, M.A. \& Staudenmaier, P.J. (2019). The relationship between entrepreneurial intent, gender and personality, Gender in Management: An International Journal, 34 (8), 666-684 